\title{
Tilbakemeldinger til studenter i allmennpraksis
}

\section{Medisinstudenter får gode tilbake- meldinger fra pasientene etter bruk av spørreskjemaet StudPEP. Lærerne er gjennomgående også fornøyd, studentene er mer kritiske til sine egne prestasjoner.}

Dette er konklusjonen på en stor undersøkelse hvor 2643 pasienter har vurdert forskjellige kvalitetsspørsmål etter endt legetime hos 173 medisinstudenter fra Universitetet i Oslo som i 2007 hadde praksisperiode hos 82 fastleger (1). Spørreskjemaet er basert på EUROPEP, et kvalitetsmålingsverktøy som er i bruk i allmennlegekorpset. Pasientene ga på 15 spørsmål gjennomsnittsskårer fra 4,3 til 4,8 på en fempunkts Likert-skala.

\section{Lavt serum-albumin - høy dødelighet}

Serum-albuminnivået ved innleggelse i akuttmedisinsk mottak har sammenheng med 30-dagersmortaliteten. De med de laveste nivåer har betydelig økt mortalitet (Eur J Int Med 2010; 21: 17-20).

Forskerne analyserte albuminnivået hos alle som ble innlagt i en akuttmedisinsk mottaksavdeling i årene 2002-08. Mortalitetsratioen var $32 \%$ ved de laveste serumalbuminverdiene. For pasienter i gruppen med de laveste $25 \%$ serum-albuminnivåene var 30-dagersmortaliteten på $20 \%$, og risikoen forble høy også etter justering for bl.a. alder, blodtransfusjon, komorbiditet og alvorlig sykdom.

\section{Mettet fett \\ gir ikke økt hjerterisiko}

Mettet fett i kosten er ikke forbundet med $ø k t$ risiko for hjerte- og karsykdom. Det viser en metaanalyse i American Journal of Clinical Nutrition (2010; 91: 535-46).

Analysen omfattet 21 prospektive epidemiologiske undersøkelser med 5-23 års oppfølgingstid - i alt 347000 friske mennesker, hvoran 11000 utviklet koronarsykdom eller apopleksi.

Inntak av mettet fett var ikke forbundet med økt risiko for koronarsykdom eller apopleksi. Vurdert sammen med andre studier bør vi ha et mer nyansert syn på det mettede fettets betydning for hjerte- og karsykdom, ifølge en kommentar i Ugeskrift for Læger (2010; 172: 1016).
Fastlegene ble bedt om å delta som observatør ved fem pasientmøter per student og gi systematisk skriftlig tilbakemelding om kvalitet og forbedringspotensial ved fire faser i konsultasjonen. I tillegg svarte de på fem spørsmål som samsvarte med pasientspørsmålene. Kombinert med tilsvarende skriftlig selvevaluering fikk dermed studentene muligheten til å sammenlikne og reflektere over strukturert tilbakemelding fra alle parter i rommet.

380 sammenliknede tilbakemeldinger ble analysert. Lærernes gjennomsnittsskårer var 4,4 på alle fem spørsmål, mot studentenes egenevalueringer på 3,6-3,8. Fritekstene fra pasienter, lærere og studenter ble kvalitativt analysert og kategorisert som «spesifikke og konkrete» versus «generelle og uspesifikke», og i artikkelen er det eksempler på begge kategorier. Prosjektet genererte støttende tilbakemeldinger til studentene, men lærernes strukturerte skriftlige tilbakemeldinger var ofte lite spesifikke, spesielt når det dreide seg om studentenes forbedringspotensial i de ulike konsultasjonsfasene. Så her har de som skal gi tilbakemelding noe å forbedre!

\section{Anja Maria Brænd \\ Sarah Frandsen Gran \\ s.f.gran@medisin.uio.no \\ Universitetet i Oslo}

\section{Litteratur}

1. Braend AM, Gran SF, Frich JC et al. Medical students' clinical performance in general practice triangulating assessments from patients, teachers and students. Med Teach 2010; 32: 333-9.

\section{Godt nytt for p-pillebrukere}

\section{Bruk av p-piller gir ikke økt dødelig- het, derimot kan det ha en gunstig effekt. Det viser en stor britisk obser- vasjonsstudie med 39 års oppfølging.}

The Royal College of General Practitioners' (RCGP) Oral Contraception Study er en av verdens største pågående studier av helseeffekter av p-pillebruk (1).

For gruppen på 46112 kvinner som ble fulgt i 39 år, var det 819175 år med p-piller brukt en eller annen gang og 378006 år uten p-pillebruk. Brukerne hadde signifikant lavere dødsrate enn ikke-brukerne (justert relativ risiko $0,88,95 \% \mathrm{KI} 0,82-0,93)$. De hadde også lavere dødsrate av alle kreftformer sett under ett og av hjerte- og karsykdom. En gruppe p-pillebrukere med økt relativ risiko for død uansett årsak var dem under 45 år som ikke hadde tatt pillen de siste 5-9 år, men ikke lenger tilbake i tid. Det var ingen sammenheng mellom totaldødelighet og varighet av p-pillebruk.

- Dette er godt nytt både for tidligere og nåværende p-pillebrukere, sier professor Ole-Erik Iversen ved Kvinneklinikken, Haukeland universitetssykehus. - Samlet anslo man at dødsrisikoen var redusert med 52/100 000 brukerår. Vi vet at mange norske kvinner er engstelige for p-piller, og det er fortsatt mange unødige uønskede graviditeter av den grunn, sier han.

- Det er også et poeng at bruken lå

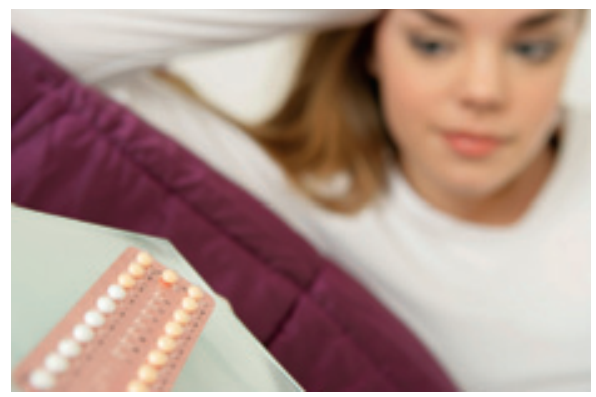

Illustrasjonsfoto (C) BSIP/GV-Press/NordicPhotos

langt tilbake i en tid da p-pillene hadde betydelig høyere hormoninnhold enn dagens. Dessuten hadde vi ikke så vel definert hvem som hadde den høyeste risikoen, f.eks. eldre røykere eller de med anamnestisk økt familiær risiko for venetrombose. Om dagens bruk innebærer ytterligere redusert risiko, kan vi bare spekulere på. Dette er ikke er en randomisert klinisk studie, og mulige skjevheter og seleksjon kan derfor ikke helt utelukkes, sier Iversen.

Trine B. Haugen

trine.b.haugen@hf.hio.no

Tidsskriftet

\section{Litteratur}

1. Hannaford PC, Iversen L, Macfarlane TV et al. Mortality among contraceptive pill users: cohort evidence from Royal College of General Practitioners' Oral Contraception Study. BMJ 2010; 340: c927. 